\title{
Using Implied Volatility to Measure Uncertainty About Interest Rates
}

\author{
Christopher J. Neely
}

\begin{abstract}
Option prices can be used to infer the level of uncertainty about future asset prices. The first two parts of this article explain such measures (implied volatility) and how they can differ from the market's true expectation of uncertainty. The third then estimates the implied volatility of threemonth eurodollar interest rates from 1985 to 2001 and evaluates its ability to predict realized volatility. Implied volatility shows that uncertainty about short-term interest rates has been falling for almost 20 years, as the levels of interest rates and inflation have fallen. And changes in implied volatility are usually coincident with major news about the stock market, the real economy, and monetary policy.
\end{abstract}

Federal Reserve Bank of St. Louis Review, May/June 2005, 87(3), pp. 407-25.

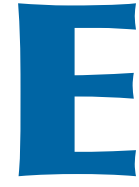

conomists often use asset prices along with models of their determination to derive financial markets' expectations of events. For example, monetary economists use federal funds futures prices to measure expectations of interest rates (Krueger and Kuttner, 1995; Pakko and Wheelock, 1996). Similarly, a large literature on fixed and target zone exchange rates has used forward exchange rates to measure the credibility of exchange rate regimes or to predict their collapse (Svensson, 1991; Rose and Svensson, 1991, 1993; Neely, 1994).

But it is often helpful to gauge the uncertainty associated with future asset prices as well as their expectation. Because option prices depend on the perceived volatility of the underlying asset, they can be used to quantify the expected volatility of an asset price (Latane and Rendleman, 1976). Such estimates of volatility, called implied volatility (IV), require some heroic assumptions about the stochastic (random) process governing the underlying asset price. But the usual assumptions seem to provide very reasonable forecasts of volatility. That is, IV is a highly significant but biased predictor of volatility, which often encompasses other forecasts.

Readers who are already familiar with the basics of options might wish to skip the first section of this article; it explains how option prices are determined by the cost of a portfolio of assets that can be dynamically traded to provide the option payoff. Readers who are unfamiliar with options might wish to start with the glossary of option terms at the end of this article and the insert on the basics of options (boxed insert 1). The second section reviews the relation between IV and future volatility, showing how option pricing formulas can be "inverted" to estimate volatility. The third section measures the IV of short-term interest rates over time and discusses how such measures can aid in interpreting economic events.

\section{HOW DOES ONE PRICE OPTIONS?}

Options are a derivative asset. That is, option payoffs depend on the price of the underlying asset. Because of this, one can often exactly replicate the payoff to an option with a suitably 


\section{BOXED INSERT 1: OPTION BASICS}

A call is an option to buy an underlying asset; a put is an option to sell the underlying asset. A European option can be exercised only at the end of its life; an American option can be exercised at any time prior to expiry.

One can either buy or sell options. In other words, one can be long or short in call options or long or short in put options. The payoff to a long position in a European call option with a strike price of $X$ is $\max \left(S_{T}-X, 0\right)$. The payoff to a long position in a European put option with a strike price of $X$ is $\max \left(X-S_{T}, 0\right)$. The payoffs to short positions are the negatives of these. The figure below shows the payoffs to the four option positions as a function of the terminal asset price for strike prices of $\$ 40$.

The relation of the current price of the underlying asset to the strike price of an option defines the option's "moneyness." Options that would net a profit if they could be exercised immediately are said to be "in the money." Options that would lose money if they were exercised immediately are "out of the money," and those that would just break even are "at the money." For example, if the underlying asset price is $\$ 50$, then a call option with a strike price of $\$ 40$ is in the money, while a put option with the same strike would be out of the money.

Because the holder of an option has limited risk from adverse price movements, greater asset price volatility tends to raise the price of an option. Because the uncertainty about the future asset price generally increases with time to expiry, options generally have "time value," meaning thatall else equal-American options with greater time to expiry will be worth more. ${ }^{1}$
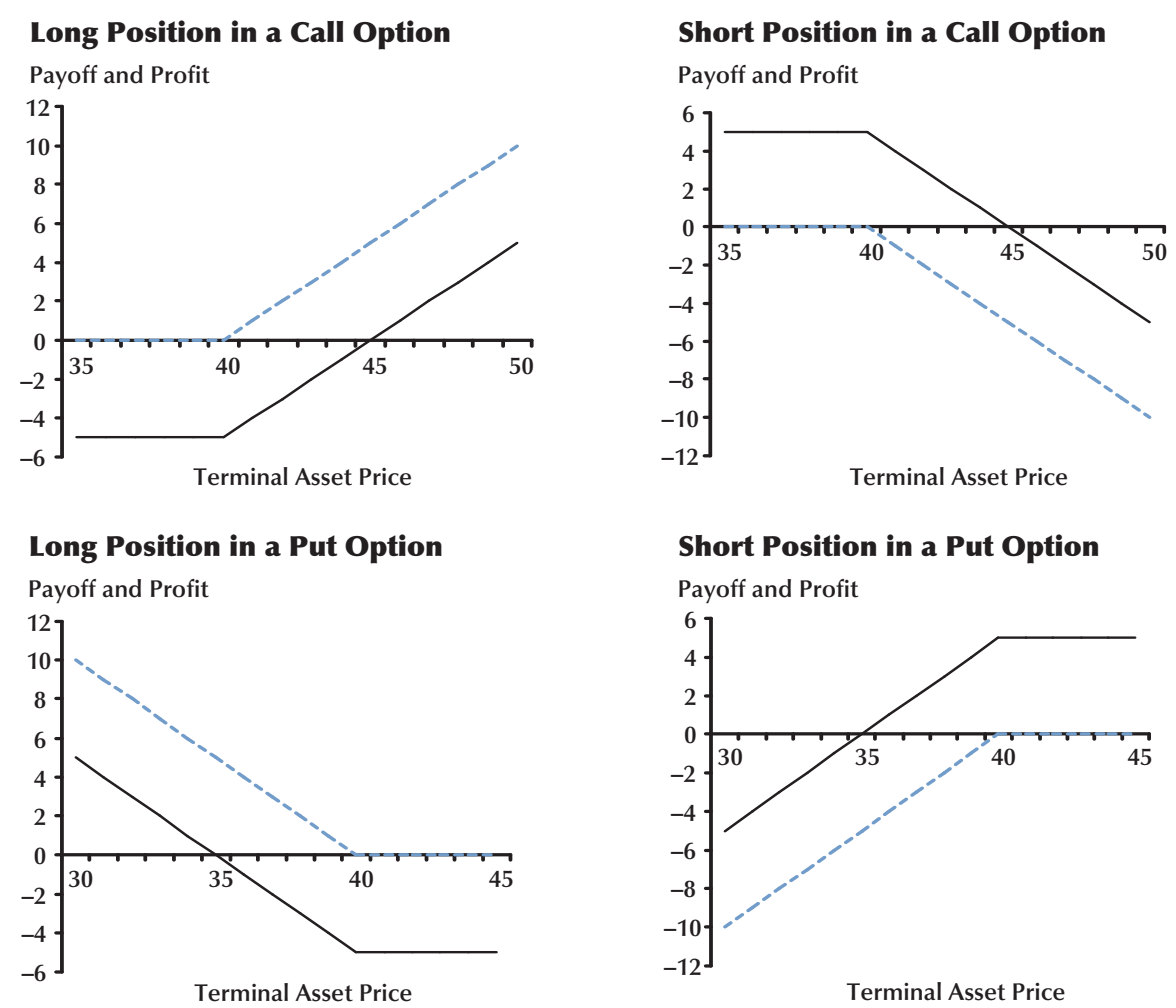

NOTE: The four figures display the payoffs (blue dashed line) and the profits (black line) for the four option positions as a function of the terminal asset price.

European options on equities can have negative time value in the presence of dividends. 
managed portfolio of the underlying asset and a riskless asset. The set of assets that replicates the option payoff is called the replicating portfolio. This section explains how arbitrage equalizes the price of the option and the price of the replicating portfolio.

\section{Pricing an Option with a Binomial Tree}

A simple numerical example will help explain how the price of an option is equal to the price of a portfolio of assets that can replicate the option payoff. Suppose that a stock price is currently $\$ 10$ and that it will either be $\$ 12$ or $\$ 8$ in one year. ${ }^{1}$ Suppose further that interest rates are currently 5 percent. A one-year European call option with a strike price of $\$ 10$ gives the buyer the right, but not the obligation, to purchase the stock for $\$ 10$ at the end of one year. ${ }^{2}$ If the stock price goes up to $\$ 12$, the option will be worth $\$ 2$ because it confers the right to pay $\$ 10$ for an asset with a $\$ 12$ market price. But if the stock price falls to $\$ 8$, the option will be worthless because no one would want to buy a stock at the strike price when the market price is lower.

Suppose that the First Bank of Des Peres (FBDP) sells one call option on one share of a nondividend-paying stock and simultaneously buys some amount, call it $\Delta$, shares of the stock. If the stock price goes up to $\$ 12$, the FBDP's portfolio will be worth the value of its stock, less the value of the option: $\$ 12 \Delta-\$ 2$. If the stock price falls to $\$ 8$, the option will be worthless and the FBDP's portfolio will only be worth $\$ 8 \Delta$. The key to option pricing is that the FBDP can choose $\Delta$ to make the value of its portfolio the same in either state of the world: It chooses $\Delta=1 / 2$, to make $\$ 12 \Delta-\$ 2=$ $\$ 8 \Delta-\$ 0$. That is, if the FBDP buys $\Delta=1 / 2$ units of the stock after selling the call option, it will have a riskless payoff to its portfolio of $\$ 4$.

Because this payoff is riskless, the portfolio of a short call option and $1 / 2$ share of the stock

\footnotetext{
1 This example assumes that the stock pays no dividends. If it did pay known dividends, it could be priced in a similar way.

2 A European option confers the right to buy or sell the underlying asset for a given price at the expiry of the option. An American option can be exercised on or before the expiry date. A call (put) option confers the right, but not the obligation, to buy (sell) a particular asset at a given price, called the strike price.
}

must earn the riskless return. If it did not, there would be an arbitrage opportunity. The initial cost of the portfolio is the cost of the $\Delta$ shares of stock $(\$ 10 \Delta)$ less the price of the call option (\$C). The initial cost of the portfolio must equal its discounted riskless payoff ( $\left.\$ 4 e^{-0.05}\right)$ :

$$
\$ 10 \Delta-C=\$ 4 e^{-0.05} .^{3}
$$

Using the fact that $\Delta=1 / 2$, the price of the call option must be

$$
C=\$ 10 \frac{1}{2}-\$ 4 e^{-0.05}=\$ 1.1951 .
$$

If the price of the call option were more than $\$ 1.1951$, one could make a riskless profit by selling the option and holding $1 / 2$ shares of the stock. ${ }^{4}$ If the call option price were less than $\$ 1.1951$, one could make an arbitrage profit by buying the call and shorting $1 / 2$ shares of the stock.

An equivalent way to look at the problem is to create the portfolio that replicates the initial investment/payoff of the call option. That is, the FBDP could borrow $\$ 5$ and buy $1 / 2$ of a share of the stock. At the end of the year, the $1 / 2$ share of stock would be worth either $\$ 6$ or $\$ 4$ and the FBDP would owe ( $\$ 5 e^{0.05}=$ ) $\$ 5.2564$ on the money it borrowed. The initial investment would be zero and the payoff would be $\$ 0.7436$ in the first state and $-\$ 1.2564$ in the second state. This is the same initial investment/payoff structure as borrowing $\$ 1.1951$ and buying the call option with a strike price of $\$ 10$. In other words, the portfolio that replicates the call option in this example is a $1 / 2$ share of the stock and an equal short position in a riskless bond.

Introductory textbooks on derivatives, like Hull (2002), Jarrow and Turnbull (2000), or Dubofsky and Miller (2003), provide a much more

3 If the continuously compounded interest rate is 5 percent, the price of a riskless bond with a one-year payoff of $\$ 4$ would have a price of $\$ 4 e^{-0.05}$.

4 Suppose that the call option cost $\$ 1.30$. One would sell the call option, borrow $\$ 3.70$, and use the proceeds of the option sale and the borrowed funds to buy $1 / 2$ share of stock. If the first state of the world occurs, the writer of the option will have $\$ 6$ in stock but will pay $\$ 2$ to the option buyer and $\left(3.70 e^{0.05}=\right) \$ 3.89$ to the bank that loaned him the funds originally. He will make a riskless profit of $\$ 0.11$. Similarly, in the second state of the world, the option expires worthless and the option writer sells the $1 / 2$ share of stock for $\$ 4$, pays the loan off with $\$ 3.89$ and again makes $\$ 0.11$ riskless profit. 


\section{Figure 1}

\section{Pricing a Call Option with a Binomial Tree}

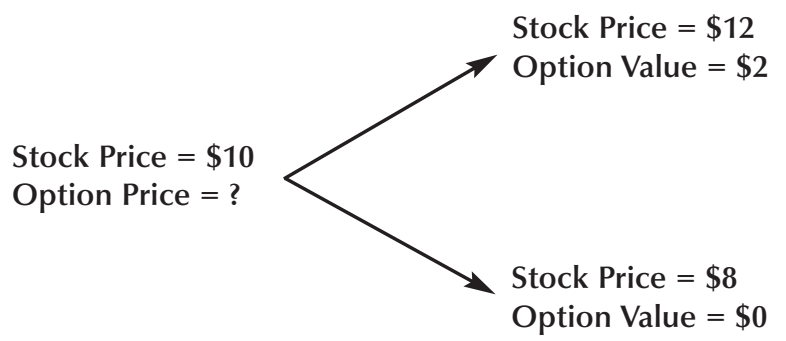

NOTE: The figure illustrates values that a hypothetical stock could take, along with the value of a call option on that stock with a strike price of $\$ 10$.

extensive treatment of binomial trees as well as information about how options pricing formulas change for different types of assets.

\section{Black-Scholes Valuation}

The preceding example, illustrated in Figure 1, was a one-step binomial tree. The option price was calculated under the assumption that the stock could take one of two known values at expiry. Suppose instead that the stock could move up or down several times before expiration. In this case, one can calculate an option price by computing each possible value of the option at expiry and working backward to get the price at the beginning of the tree. As the asset prices rise and the call option goes "into the money," the replicating portfolio holds more of the underlying asset and less of the riskless bond. ${ }^{5}$ At each point in time, the option writer chooses the position in the underlying asset to maintain a riskless payoff to the hedged portfolio-the combination of the positions in the option, the underlying asset, and the riskless bond. The position in the underlying asset is equal to the rate of change in the option value with respect to the underlying asset price.

\footnotetext{
5 A call (put) option is said to be "in the money" if the underlying asset price is greater (less) than the strike price. If the underlying asset price is less (greater) than the strike price, the call (put) option is "out of the money." When the underlying asset price is near (at) the strike price, the option is "near (at) the money."
}

This rate of change is known as the option's "delta" and the continuous process of adjustment of the underlying asset position is known as "delta hedging." The limit of the formula for an option price from an $n$-step binomial tree, as $n$ goes to infinity, is the Black-Scholes (BS) formula (Black and Scholes, 1972). ${ }^{6}$

The BS formula expresses the value of a European call or put option as a function of the underlying asset price $(S)$, the strike price $(X)$, the interest rate $(r)$, time to expiry $(T)$, and the variance of the underlying asset return $\left(\sigma^{2}\right)$. Higher asset price volatility means higher option prices because the downside risk is always limited, whereas the upside potential is not. Therefore, option prices increase with expected volatility. The formula for the price of a European call option on a spot asset that pays no dividends or interest is the following:

where $d_{1}=\frac{\ln \left(S_{0} / X\right)+\left(r+\sigma^{2} / 2\right) T}{\sigma \sqrt{T}}$ and

$$
d_{2}=\frac{\ln \left(S_{0} / X\right)+\left(r-\sigma^{2} / 2\right) T}{\sigma \sqrt{T}}=d_{1}-\sigma \sqrt{T}
$$

and $N\left({ }^{*}\right)$ is the cumulative normal density function. Hull (2002), Jarrow and Turnbull (2000), and Dubofsky and Miller (2003) provide formulas for put options and options on other types of assets.

The BS formula strictly applies to European options only—not to American options, which can be exercised any time prior to expiry-and it requires modifications for assets that pay dividends, such as stocks, or that don't require an initial outlay, such as futures. ${ }^{7}$ Further, the BS model makes some strong assumptions: that the underlying asset price follows a lognormal random walk, that the riskless rate is a known function of time, that one can continuously adjust one's

\footnotetext{
6 There are several ways to derive the BS formula that differ in their required assumptions (Merton, 1973b). Wilmott, Howison, and Dewynne (1995) provide a nice introduction to the mathematics of the BS formula and Wilmott (2000) extends that treatment to cover the price of volatility risk. Boyle and Boyle (2001) discuss the history of option pricing formulas.

7 Black (1976) provides the formula for options on futures, rather than spot assets. Barone-Adesi and Whaley (1987) provide an approximation to the BS formula that accounts for early exercise.
} 
position in the underlying asset (delta hedging), and that there are no transactions costs on the underlying asset and no arbitrage opportunities. Despite these strong assumptions, the BS model is very widely used by practitioners and academics, often fitting the data reasonably well even when its assumptions are clearly violated.

\section{Does IV Predict Realized Volatility?}

The BS model expresses the price of a European call or put option $(C$ or $P$ ) as a function of five arguments $\left\{S, X, r, T\right.$, and $\left.\sigma^{2}\right\}$. Of those six quantities, five are observable as market prices or features of the option contract $\{C, S, X, r, T\}$. The BS formula is frequently inverted to solve for the sixth quantity, the IV $\{\sigma\}$ of log asset returns in terms of the observed quantities. This IV is used to predict the volatility of the asset return to expiry.

Ironically, the BS formula usually used to derive IV assumes that volatility is constant. Hull and White (1987) provide the foundation for the practice of using a constant-volatility model to predict stochastic volatility (SV): If volatility evolves independently of the underlying asset price and no priced risk is associated with the option, the correct price of a European option equals the expectation of the BS formula, evaluating the variance argument at average variance until expiry:

$$
\begin{aligned}
C\left(S_{t}, V_{t}, t\right) & =\int_{t}^{T} C^{B S}(\bar{V}) h\left(\bar{V} \mid \sigma_{t}^{2}\right) d \bar{V} \\
& =E\left[C^{B S}\left(\bar{V}_{t, T}\right) \mid V_{t}\right],
\end{aligned}
$$

where the average variance until expiry is denoted as

$$
\bar{V}_{t, T}=\frac{1}{T-t} \int_{\tau}^{T} V_{\tau} d \tau
$$

and its square root is usually referred to as realized volatility $(\mathrm{RV}){ }^{8}$

Bates (1996) points out that the expectation in (4) is taken with respect to variance until expiry, not standard deviation until expiry. Therefore, one cannot use the linearity of the BS formula with respect to standard deviation to justify pass-

8 Romano and Touzi (1997) extend the Hull and White (1987) result to include models that permit arbitrary correlation between returns and volatility, like the Heston (1993) model. ing the expectation through the BS formula. That is, one cannot claim that the correct price of a call option under stochastic volatility is the BS price evaluated at the expected value of the standard deviation until expiry. That is, it is not true that

$$
C\left(S_{t}, \sqrt{V_{t}}, t\right)=C^{B S}\left(E \sqrt{\bar{V}}_{t, T} \mid V_{t}\right) .
$$

Instead, Bates (1996) approximates the relation between the BS IV and expected variance until expiry with a Taylor series expansion of the BS price for an at-the-money option. That is, for atthe-money options, the BS formula for futures reduces to

$$
C^{B S}=e^{-r T} F\left[2 N\left(\frac{1}{2} \sigma \sqrt{T}\right)-1\right] .
$$

This can be approximated with a second-order Taylor expansion of $N\left(^{*}\right)$ around zero, which yields

$$
C^{B S} \approx e^{-r T} F \sigma \sqrt{T /(2 \pi)} .
$$

Another second-order Taylor expansion of that approximation around the expected value of variance until expiry shows that the BS IV is approximately the expected variance until expiry:

$$
\hat{\sigma}_{B S}^{2} \approx\left(1-\frac{1}{8} \frac{\operatorname{Var}\left(\bar{V}_{t, T}\right)}{\left(E_{t} \bar{V}_{t, T}\right)^{2}}\right)^{2} E_{t} \bar{V}_{t, T} .
$$

That is, the BS-implied variance $\left(\sigma_{\mathrm{BS}}^{2}\right)$ understates the expected variance of the asset until expiry $\left(E_{t} \bar{V}_{t, T}\right)$. Similarly, BS-implied standard deviation $\left(\sigma_{\mathrm{BS}}\right)$ slightly understates the expected standard deviation of asset returns. ${ }^{9}$

\section{The Volatility Smile}

Volatility is constant in the BS model; IV does not vary with the "moneyness" of the option. That is, if the BS model assumptions were literally true, the IV from a deep-in-the-money call should be the same as that from an at-the-money call or an in-the-money put. In reality, for most assets, IV does vary with moneyness. A graph of IV versus moneyness is often referred to as the "volatility

\footnotetext{
9 Note that (6) depends on (4), which assumes that there is no priced risk associated with holding the option. That is, (6) requires that changes in volatility do not create priced risk for an option writer.
} 
smile" or "volatility smirk," depending on the shape of the relation. Research attributes the volatility smile to deviations from the BS assumptions about the evolution of the underlying asset prices, such as the presence of stochastic volatility, jumps in the price of the underlying asset, and jumps in volatility (Bates, 1996, 2003).

The existence of the volatility smile brings up the question of which strike prices-or combinations of strike prices-to use to compute IV. In practice, IV is usually computed from a few nearthe-money options for three reasons (Bates, 1996): (i) The BS formula is most sensitive to IV for atthe-money options. (ii) Near-the-money options are usually the most heavily traded, resulting in smaller pricing errors. (iii) Beckers (1981) showed that IV from at-the-money options provides the best estimates of future realized volatility. While researchers have varied the number and types of options as well as the weighting procedure, it has been common to rely heavily on a few at-themoney options.

\section{Constructing IV from Options Data}

At each date, IV is chosen to minimize the unweighted sum of squared deviations of BaroneAdesi and Whaley's (1987) formula for pricing American options on futures with the actual settlement prices for the two nearest-to-the-money call options and two nearest-to-the-money put options for the appropriate futures contract. ${ }^{10}$ That is, IV is computed as follows:

$$
\sigma_{I V, t, T}=\arg \min _{\sigma_{t, T}} \sum_{i=1}^{4}\left(B A W_{i}\left(\sigma_{t, T}\right)-P r_{i, t}\right)^{2}
$$

where $\operatorname{Pr}_{i, t}$ is the observed settlement premium (price) of the ith option on day $t$ and $B A W_{i}\left({ }^{*}\right)$ is the appropriate call or put formula as a function of the IV.

Before being used in the minimization of (7), the data were checked to make sure that they obeyed the inequality restrictions implied by the no-arbitrage conditions on American options prices: $C \geq F-X$ and $P \geq X-F$, where $F$ is the

\footnotetext{
${ }^{10}$ The results in this paper are almost indistinguishable when done with European option pricing formulas (Black, 1976) or the BaroneAdesi and Whaley correction for American options.
}

price of the underlying futures contract. These conditions apply because an American optionwhich can be exercised at any time-must always be worth at least its value if exercised immediately. Options prices that did not obey these relations were discarded. In addition, the observation was discarded if there was not at least one call and one put price.

\section{THE PROPERTIES OF IMPLIED VOLATILITY}

\section{How Well Does IV Predict RV?}

Equation (6) says that BS IV is approximately the conditional expectation of $\operatorname{RV}\left(\bar{V}_{t, T}\right)$. This relation has two testable implications: IV should be an unbiased predictor of RV; no other forecast should improve the forecast from IV. If IV is an unbiased predictor of RV, one should find that $\left\{\alpha, \beta_{1}\right\}=\{0,1\}$ in the following regression:

$$
\sigma_{R V, t, T}=\alpha+\beta_{1} \sigma_{I V, t, T}+\varepsilon_{t}
$$

where $\sigma_{R V, t, T}$ denotes the RV of the asset return from time $t$ to $T$ and $\sigma_{I V, t, T}$ is IV at $t$ for an option expiring at $T .{ }^{11} \mathrm{RV}$ is the annualized standard deviation of asset returns from $t$ to $T$ :

$$
\sigma_{R V, t, T}=\sqrt{\bar{V}_{t, T}}=\sqrt{\frac{250}{T-t} \sum_{i=t}^{T} \ln \left(F_{i} / F_{i-1}\right)},
$$

where $F_{t}$ is the asset price at $t$ and there are 250 business days in the year.

The other commonly investigated hypothesis about IV is that no other forecast improves its forecasts of RV. If IV does subsume other information in this way, it is said to be an "informationally efficient predictor" of volatility. Researchers investigate this issue with variants of the following encompassing regression:

$$
\sigma_{R V, t, T}=\alpha+\beta_{1} \sigma_{I V, t, T}+\beta_{2} \sigma_{F V, t, T}+\varepsilon_{t},
$$

\footnotetext{
${ }^{11}$ Researchers also estimate (8) with realized and implicit variances, rather than standard deviations. The results from such estimations provide similar inference to those done with variances. Other authors argue that because volatility is significantly skewed, one should estimate (8) with log volatility. Equation (6) shows that use of logs introduces another source of bias into the theoretical relation between RV and IV.
} 
where $\sigma_{F V, t T}$ is some alternative forecast of volatility from $t$ to $T .^{12}$ If one rejects that $\beta_{2}=0$ for some $\sigma_{F V, t, T}$, then one rejects that IV is informationally efficient.

Across many asset classes and sample periods, researchers estimating versions of (8) have found that $\hat{\alpha}$ is positive and $\hat{\beta}_{1}$ is less than 1 (Canina and Figlewski, 1993; Lamoureux and Lastrapes, 1993; Jorion, 1995; Fleming, 1998; Christensen and Prabhala, 1998; Szakmary et al., 2003). That is, IV is a significantly biased predictor of RV: A given change in IV is associated with a larger change in RV.

Tests of informational efficiency provide more mixed results. Kroner, Kneafsey, and Claessens (1993) concluded that combining time-series information with IV could produce better forecasts than either technique singly. Blair, Poon, and Taylor (2001) discover that historical volatility provides no incremental information to forecasts from VIX IVs. ${ }^{13} \mathrm{Li}$ (2002) and Martens and Zein (2004) find that intraday data and long-memory models can improve on IV forecasts of RV in currency markets.

It is understandable that tests of informational efficiency provide more varied results than do tests of unbiasedness. Because theory does not restrict what sort of information could be tested against IV, the former tests suffer a data snooping problem. Even if IV is informationally efficient, some other forecasts will improve its predictions in a given sample, purely as a result of sampling variation. These forecasts will not add information to IV in other periods, however.

But some authors have found reasonably strong evidence against the simple informational efficiency hypothesis across assets and classes of forecasts (Neely, 2004a,b). This casts doubt on the data snooping explanation. It seems likely that IV is not informationally efficient by statistical

\footnotetext{
${ }^{12}$ One need not make the econometric forecast orthogonal to IV before using it in (10). The $\hat{\beta}_{2} t$-statistic provides the same asymptotic inference as the appropriate $F$-test for the null that $\beta_{2}=0$. And the $F$-test is invariant to orthogonalizing the regressors because it is based on the regression $\mathrm{R}^{2}$.

${ }^{13}$ VIX is a weighted index of IVs calculated from near-the-money, short-term, S\&P 100 options. It is designed to correct measurement problems associated with the volatility smile and early exercise.
}

criteria and that the failure of unbiasedness and inefficiency are related.

Several hypotheses have been put forward to explain the conditional bias: errors in IV estimation, sample selection bias, estimation with overlapping observations, and poor measurement of RV. Perhaps the most popular solution to the conditional bias puzzle is the claim that volatility risk is priced. This theory requires some explanation.

\section{The Price of Volatility Risk}

To understand the volatility risk problem, consider that there are two sources of uncertainty for an option writer - the agent who sells the option-if the volatility of the underlying asset can change over time: the change in the price of the underlying asset and the change in its volatility. ${ }^{14}$ An option writer would have to take a position both in the underlying asset (delta hedging) and in another option (vega hedging) to hedge both sources of risk. ${ }^{15}$ If the investor only hedges with the underlying asset-not using another option too-then the return to the investor's portfolio is not certain. It depends on changes in volatility. If such volatility fluctuations represent a systematic risk, then investors must be compensated for exposure to them. In this case, the HullWhite result (4) does not apply because there will be risk associated with holding the option and the IV from the BS formula will not approximate the conditional expectation of objective variance as in (6).

The idea that volatility risk might be priced has been discussed for some time: Hull and White (1987) and Heston (1993) consider it. Lamoureux and Lastrapes (1993) argued that the price of volatility risk was likely to be responsible for the bias in IVs options on individual stocks. But most empirical work has assumed that this volatility risk premium is zero, that volatility risk could be hedged or is not priced.

\footnotetext{
${ }^{14}$ A more general model would imply additional sources of risk such as discontinuities (jumps) in the underlying asset price or underlying volatility.

${ }^{15}$ Delta and vega denote the partial derivatives of the option price with respect to the underlying asset price and its volatility, respectively.
} 
Is it reasonable to assume that the volatility risk premium is zero? There is no question that volatility is stochastic, options prices depend on volatility, and risk is ubiquitous in financial markets. And if customers desire a net long position in options to hedge against real exposure or to speculate, some agents must hold a net short position in options. Those agents will be exposed to volatility fluctuations. If that risk is priced in the asset pricing model, those agents must be compensated for exposure to that risk. These facts argue that a non-zero price of volatility risk creates IV's bias.

On the other hand, there seems little reason to think that volatility risk itself should be priced. While the volatility of the market portfolio is a priced factor in the intertemporal capital asset pricing model (CAPM) (Merton, 1973a; Campbell, 1993), it is more difficult to see why volatility risk in other markets-e.g., foreign exchange and commodity markets-should be priced. One must appeal to limits-of-arbitrage arguments (Shleifer and Vishny, 1997) to justify a non-zero price of currency volatility risk.

Recently, researchers have paid greater attention to the role of volatility risk in options and equity markets (Poteshman, 2000; Bates, 2000; Benzoni, 2002; Chernov, 2002; Pan, 2002;

Bollerslev and Zhou, 2003; and Ang et al., 2003). Poteshman (2000), for example, directly estimated the price of risk function and instantaneous variance from options data, then constructed a measure of IV until expiry from the estimated volatility process to forecast SPX volatility over the same horizon. Benzoni (2002) finds evidence that variance risk is priced in the S\&P 500 option market. Using different methods, Chernov (2002) also marshals evidence to support this price of volatility risk thesis. Neely (2004a,b) finds that Chernov's price-of-risk procedures do not explain the bias in foreign exchange and gold markets.

\section{THE IMPLIED VOLATILITY OF SHORT-TERM INTEREST RATES}

The IV of options on short-term interest rates illustrates how IV might be applied to understand economic forces. Central banks are particularly concerned with short-term interest rates because most central banks implement monetary policy by targeting those rates. ${ }^{16}$ Financial market participants and businesses likewise often carefully follow the actions and announcements of central banks to better understand the future path of short-term interest rates.

\section{Eurodollar Futures Contracts}

Interest rate futures are derivative assets whose payoffs depend on interest rates on some date or dates in the future. They enable financial market participants to either hedge their exposure to interest rate fluctuations, or speculate on interest rate changes. One such instrument is the Chicago Mercantile Exchange futures contract for a three-month eurodollar time deposit with a principal amount of $\$ 1,000,000$. The final settlement price of this contract is 100 less the British Bankers' Association (BBA) three-month eurodollar rate prevailing on the second London business day immediately preceding the third Wednesday of the contract month:

$$
F_{T}=100=R_{T},
$$

where $F_{T}$ is the final settlement price of the futures contract and $R_{T}$ is the BBA three-month rate on the contract expiry date. The relation between the three-month eurodollar rate at expiry and the final settlement price ties the futures price at all dates to expectations of this interest rate.

For concreteness, consider what would happen if the First Bank of Des Peres (FBDP) sold a three-month eurodollar futures contract for a quoted price of $\$ 97$ on June 7,2004 , for a contract expiring on September 13, 2004. Banks might take such short positions to hedge interest rate fluctuations; they borrow short-term and lend long-term and will generally lose (gain) when short-term interest rates rise (fall). The FBDP's

\footnotetext{
16 The fact that central banks implement policy by targeting shortterm interest rates does not mean that nominal interest rates can be interpreted as measuring the stance of monetary policy. For example, if inflation rises and interest rates remain constant, policy passively becomes more accommodative, all else equal.
} 
short position means that it has effectively agreed to borrow $\$ 1,000,000$ for three months, starting on September 13, 2004, at an interest rate of $(100-97=) 3$ percent.

If the market had expected no change in interest rates through September and risk premia in this market are constant, then realized changes in spot interest rates will translate directly into changes in futures prices. ${ }^{17}$ If interest rates unexpectedly rise 45 basis points between June 7, 2004, and September 13, 2004, the FBDP futures prices will fall and the FBDP will have gained by precommitting to borrow at 3 percent. If interest rates unexpectedly decline, however, the FBDP will lose on the futures contract.

How much will the FBDP gain (lose) for each basis-point decrease (increase) in interest rates? With quarterly compounding it will gain 1 basis point of interest for one quarter of a year on $\$ 1,000,000$. This translates to $\$ 25$ per basis point.

$$
\$ 1,000,000 \frac{0.0001}{4}=\$ 25 \text {. }
$$

If the BBA three-month eurodollar rate is 3.45 percent on the day of final settlement, the final settlement price of the futures contract will be $100-3.45=96.55$ percent. The FBDP will gain $\$ 25 \times 45=\$ 1,125$ because it shorted the contract at $\$ 97$ and the contract price fell to $\$ 96.55$ at final settlement. ${ }^{18}$ Such a gain would be used to offset losses from the reduced value of its asset portfolio (loans).

Because the final futures price will be determined by the BBA three-month eurodollar rate at final settlement, the futures price can be used to infer the expected future interest rate if there is no risk premium associated with holding the futures contract. Or, if there are stable risk premia associated with holding the contract, one can still measure changes in expected interest rates from changes in futures prices if the risk premia are fairly stable.

\footnotetext{
${ }^{17}$ More generally, only unanticipated changes in interest rates will result in changes in futures prices and risk premia will play some role in futures returns.

${ }^{18}$ This example assumes the FBDP holds the position until final settlement.
}

\section{Splicing the Futures and Options Data}

To examine the behavior of IV on short-term interest rates, we consider settlement data on each three-month eurodollar futures and option contract for the period March 20, 1985, through June 29, 2001. Because exchange-traded futures and options contracts expire on only a few dates a year, one cannot obtain a series of options priced with a fixed expiry horizon for each business day of the year. ${ }^{19}$ To obtain as much information as possible, the usual practice in dealing with futures and options data is to "splice" data from different contracts at the beginning of some set of contract expiry months, usually monthly or quarterly. This article uses data from futures and options contracts expiring in March, June, September, and December. For example, settlement prices for the futures contract and the two nearest-the-money call and put options expiring in March 1986 are collected for all trading days in December 1985 and January and February 1986. Then data pertaining to June 1986 contracts are collected from March, April, and May 1986 trading dates. A similar procedure is followed for the September and December contracts. Such a procedure avoids pricing problems near final settlement that result from illiquidity (Johnston, Kracaw, and McConnell, 1991). This method collects data on a total of 4,040 business days, with 8 to 76 business days to option expiry.

\section{Summary Statistics}

Table 1 shows the summary statistics on log futures price changes in percentage terms, absolute log futures price changes in annual terms, and IV and RV in annual terms. Futures price changes are very close to mean-zero and have some modest positive autocorrelation. The absolute changes are definitely positively autocorrelated, as one would expect from high-frequency asset price data. IV and RV until expiry have similar mean and autocorrelation properties. But IV is somewhat less volatile than RV, as one would expect if IV predicts RV. The mean of RV is slightly lower

\footnotetext{
19 Additional expiry months were introduced in 1995; previously,
} there were four expiry months per year. 


\section{Table 1}

\section{Summary Statistics}

\begin{tabular}{lcccc} 
& $\mathbf{1 0 0} \cdot \mathbf{I n}(\boldsymbol{F}(\boldsymbol{t}) / \boldsymbol{F}(\boldsymbol{t} \mathbf{- 1}))$ & $\mathbf{2 4 9} \cdot \mathbf{1 0 0} \cdot|\boldsymbol{I n}(\boldsymbol{F}(\boldsymbol{t}) / \boldsymbol{F}(\boldsymbol{t} \mathbf{- 1}))|$ & $\sigma_{\boldsymbol{I V}, \boldsymbol{t}, \boldsymbol{I}}$ & $\sigma_{\boldsymbol{R}, \boldsymbol{t}, \boldsymbol{T}}$ \\
\hline Total observations & 4,040 & 4,040 & 4,040 & 4,040 \\
Nobs & 3,975 & 3,975 & 3,953 & 4,039 \\
$\mu$ & 0.003 & 10.088 & 0.953 & 0.769 \\
$\sigma$ & 0.070 & 14.141 & 0.458 & 0.494 \\
Max & 1.272 & 316.645 & 3.601 & 3.861 \\
Min & -0.449 & 0.000 & 0.251 & 0.076 \\
$\rho_{1}$ & 0.070 & 0.213 & 0.986 & 0.989 \\
$\rho_{2}$ & 0.023 & 0.241 & 0.973 & 0.977 \\
$\rho_{3}$ & -0.014 & 0.226 & 0.960 & 0.965 \\
$\rho_{4}$ & -0.025 & 0.246 & 0.948 & 0.954 \\
$\rho_{5}$ & -0.007 & 0.247 & 0.936 & 0.942
\end{tabular}

NOTE: The table contains summary statistics on log futures price changes (percent), annualized absolute log futures price changes, and annualized IV and RV until expiry. The rows show the total number of observations in the sample, the non-missing observations, the mean, the standard deviation, the maximum, the minimum, and the first five autocorrelations. The standard error of the autocorrelations is about $1 / \sqrt{ } T \approx 0.016$.

than that of IV, indicating that there might be a volatility premium.

Figure 2 clearly illustrates the right skewness in the distribution of IV and changes in IV. Although it is difficult to see in the lower panel of Figure 2, very large positive changes in IV are much more common than very large negative changes in IV. The fact that IV must be positive probably partly explains the right skewness in these distributions.

\section{Eurodollar Rates and the Federal Funds Target Rate}

The futures and options data considered here pertain to three-month eurodollar rates. The Fed, however, is more concerned about the federal funds rate, the overnight interbank interest rate used to implement monetary policy, than about other short-term interest rates, such as the eurodollar rate. ${ }^{20}$ This is because the federal funds futures prices are often interpreted to provide market expectations of the Fed's near-term policy actions. Short-term interest rates are closely tied

${ }^{20}$ Carlson, Melick, and Sahinoz (2003) describe the recently developed options market on federal funds futures contracts. together, however, so there might be information about the federal funds rate in three-month eurodollar futures.

Figure 3 shows that, although the three-month eurodollar is much more variable than the federal funds target over a period of a few days, the two series closely tracked each other over periods longer than a few days from March 1985 through June 2001. One can assume that the expected path of the funds rate is closely related to the expected path of the three-month eurodollar rate. ${ }^{21}$ And therefore the IV on three-month eurodollars probably tracks the uncertainty about the federal funds target over horizons greater than a few days.

\section{Options on Eurodollar Rates}

Because option prices depend on the volatility of the underlying asset (among other factors), one can measure the uncertainty associated with expectations of future interest rates from IV from option prices on eurodollar futures contracts. And

\footnotetext{
${ }^{21}$ The payoff to the federal funds futures contract depends on the average federal funds rate over the course of a month, whereas the three-month eurodollar futures contract payoff depends on the BBA quote for the three-month eurodollar rate at one point in time, the expiry of the contract.
} 


\section{Figure 2}

\section{The Distributions of Implied Volatility and Changes in Implied Volatility}
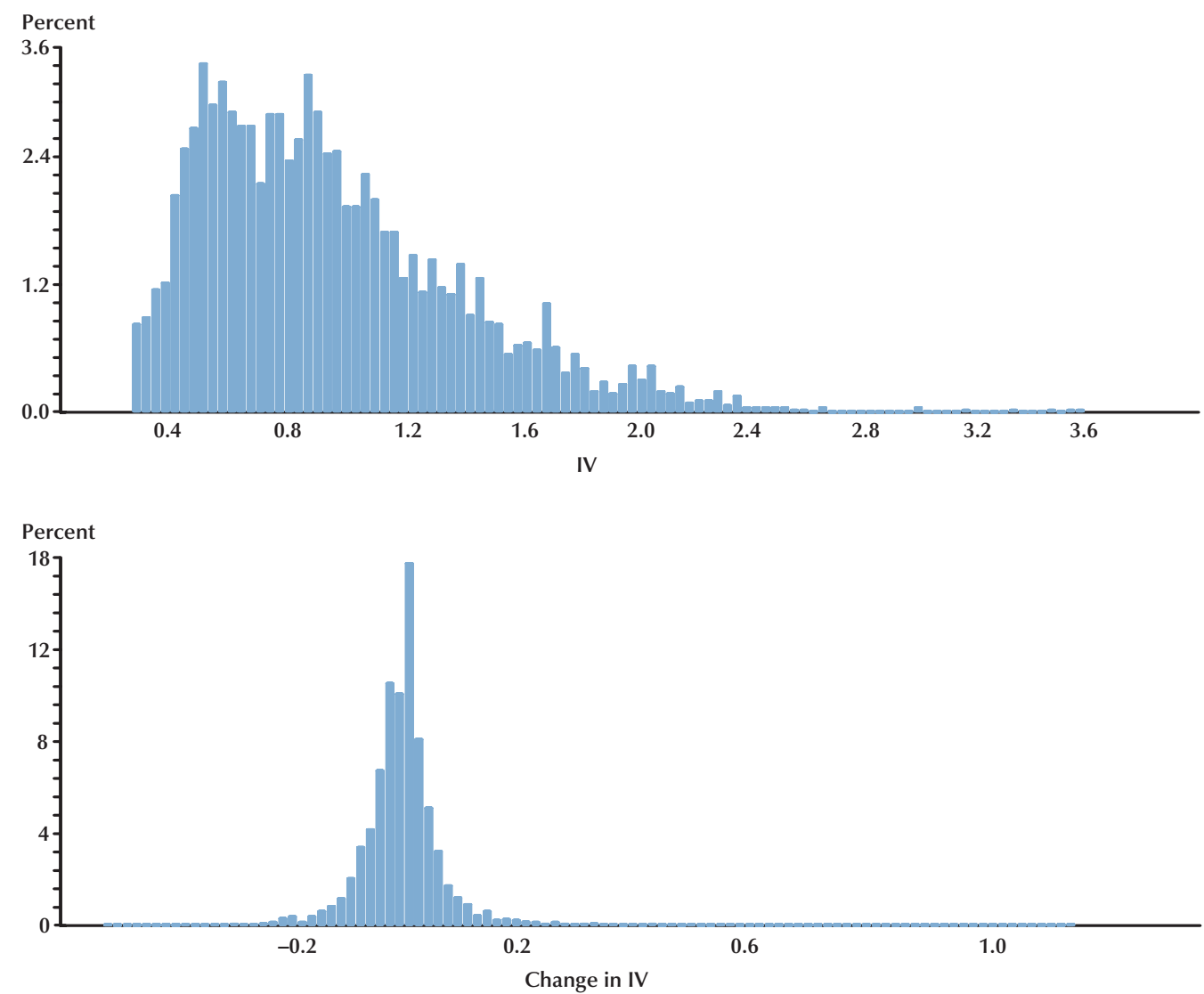

NOTE: The figure shows the empirical distributions of IV and changes in IV on three-month eurodollar futures prices.

the volatility of interest rates will be very close to the volatility of futures prices because of the linear relation between the two series at final settlement: $100-F_{T}=R_{T}$.

The usual BS measure of IV is a risk-neutral measure, meaning that it assumes that all risk associated with holding the option can be arbitraged away. ${ }^{22}$ This is probably not exactly true. And the eurodollars futures prices don't necessarily follow the assumptions of the BS model. In particular, the underlying asset price is probably subject to jumps. Yet Figure 4, which shows the

${ }^{22}$ Boxed insert 2 explains the concept of risk-neutral measures.
IV and RV until expiry of the three-month eurodollars futures price, appears to show that the BS IV tracks RV fairly well. So, one might think that IV from options on three-month eurodollar rates measures the uncertainty about future interest rates reasonably well.

\section{How Well Does IV Predict RV for Eurodollar Futures?}

One can test the unbiasedness hypothesisthat IV is an unbiased predictor of RV-with the predictive regression (8):

$$
\sigma_{R V, t, T}=\alpha+\beta_{1} \sigma_{I V, t, T}+\varepsilon_{t} .
$$




\section{BOXED INSERT 2: RISK-NEUTRAL VALUATION}

The calculation of the price of the option in Figure 1 did not include any assumptions about the probabilities that the stock price would rise or fall. But the assumptions used to value the stock do imply "risk-neutral probabilities" of the two states of the world. These are the probabilities that equate the expected payoff on the stock with the payoff to a riskless asset that requires the same initial investment. Recall that the stock in the example in Figure 1 was worth $\$ 12$ in the first state of the world and $\$ 8$ in the second state of the world. If the initial price of the stock is $\$ 10$, the riskneutral probabilities solve the following:

$$
p \cdot \$ 12+(1-p) \cdot \$ 8=\$ 10 e^{0.05} .
$$

This implies that-if prices were unchanged and stocks were valued by risk-neutral investors-the probability that the stock price rises-the probability of state 1-is the following:

$$
p=\frac{\left(10 e^{0.05}-8\right)}{12-8}=0.6282 \text {. }
$$

It is important to understand that this risk-neutral probability is not the objective probability that the stock price will rise. It is a synthetic probability that the stock price will rise if actual prices had been determined by risk-neutral agents.

No assumption in this example provides the objective probability that the stock price will rise; neither can one calculate the expected return to the stock. But even without the objective probabilities, one could calculate the option price through the assumption of the absence of arbitrage. It is counterintuitive but true that the expected return on the stock is not needed to value a call option. One might think that a call option would depend positively on the expected return to the stock. But, because one can value the option through the absence of arbitrage, the expected return to the stock doesn't explicitly appear in the option pricing formula.

And the risk-neutral probabilities can be used to calculate the value of the option $(\$ C)$ by discounting the value of the (risk-neutral) expected option payoff. Recalling that the option is worth $\$ 2$ in the first state of the world, which has a probability of 0.6282 and $\$ 0$ in the second state of the world, the option price can be calculated as the discounted risk-neutral expectation of its payoff as follows:

$$
C=e^{-0.05}[p \cdot 2+(1-p) \cdot 0]=e^{-0.05}[0.6282 \cdot 2+(1-0.6282) \cdot 0]=\$ 1.1951 .
$$

This calculation provides the same answer as the no-arbitrage argument used in Figure 1. In some cases, it is easier to derive option pricing formulas from a risk-neutral valuation.

The concept of risk-neutral valuation implies that IV from option prices measures the volatility of the risk-neutral probability measure. To the extent that an asset price's actual stochastic process differs from a risk-neutral process, perhaps because there is a risk-premium in its drift or a volatility risk premium in the option price, the information obtained by inverting option pricing formulas will be misleading. The true distribution of the underlying asset price is often called the objective probability measure. 


\section{Figure 3}

\section{Federal Funds Targets and Three-Month Eurodollar Rates}

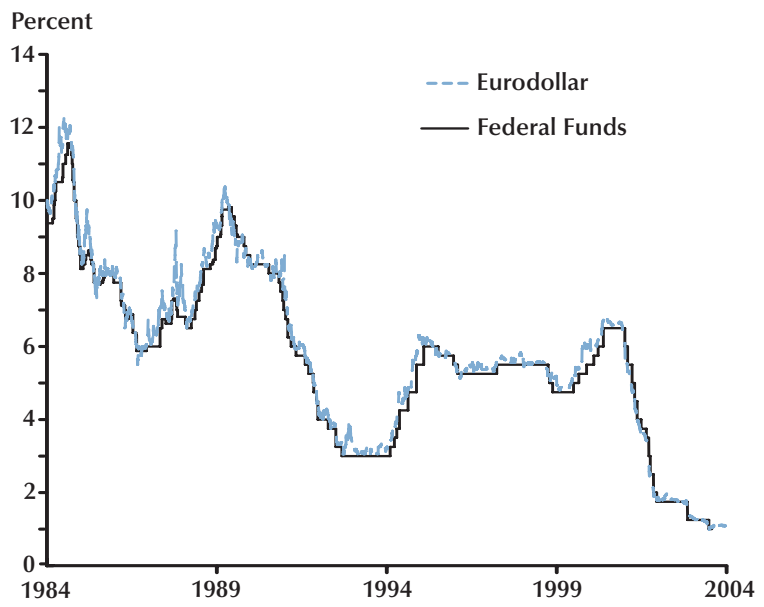

NOTE: The figure displays federal funds targets and the threemonth eurodollar rate from January 1, 1984, to July 25, 2003.

For overlapping horizons, the residuals in (8) will be autocorrelated and, while ordinary least squares (OLS) estimates are still consistent, the autocorrelation must be dealt with in constructing standard errors (Jorion, 1995). Such data sets are described as "telescoping" because correlation between adjacent errors declines linearly and then jumps up at the point at which contracts are spliced.

Table 2 shows the results of estimating (8) with $\sigma_{I V, t, T}$ and $\sigma_{R V, t, T}$ on three-month eurodollar futures. $\hat{\beta}_{1}$ is statistically significantly less than $1-0.83$-indicating that IV is an overly volatile predictor of subsequent RV. This is the usual finding from such regressions: See Canina and Figlewski (1993), Lamoureux and Lastrapes (1993), Jorion (1995), Fleming (1998), Christensen and Prabhala (1998), and Szakmary et al. (2003), for example. As discussed previously, there are many potential explanations for this conditional bias-sample selection, overlapping data, errors in IV-but the most popular story is that stochastic volatility introduces risk to delta hedging, making writing options risky.

\section{Figure 4}

\section{Realized and Implied Volatility on Three-Month Eurodollar Rates}

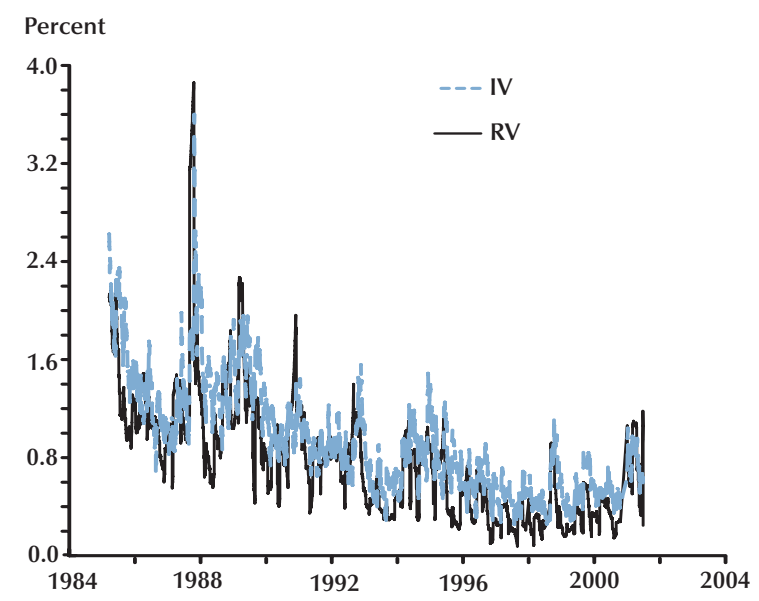

NOTE: The figure displays three-month eurodollar IV and RV from March 20, 1985, through June 29, 2001.

Figure 5 shows a scatterplot of $\{\mathrm{IV}, \mathrm{RV}\}$ pairs along with the OLS fitted values from Table 2, a 45-degree line and the mean of IV and RV. If IV were an unbiased predictor of RV, the 45-degree line would be the true relation between them. The fact that the OLS line is flatter than the 45degree line illustrates that IV is an overly volatile predictor of RV. The cross in Figure 5-which is centered on \{mean IV, mean RV\}-lies beneath the 45-degree line, illustrating that the mean IV is higher than mean RV.

\section{What Does IV IIlustrate About Uncertainty About Future Interest Rates?}

Comparing Figure 3 with Figure 4 shows that IV has been declining with the overall level of short-term interest rates, which have been falling with inflation since the early 1980s. One interpretation of the data is that the sharp rise in inflation in the 1970s and the subsequent disinflation of the 1980s created much uncertainty about the level of future interest rates, which has gradually fallen over the past 20 years. The reduction in uncertainty with respect to interest rates probably 


\section{Figure 5}

\section{Implied Volatility as a Predictor of Realized Volatility}

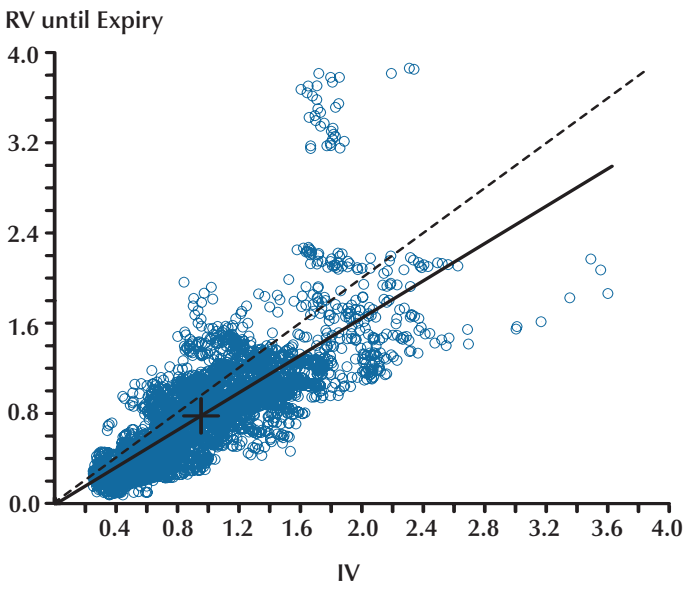

NOTE: The figure shows a scatterplot of $\{I V, R V\}$ pairs along with the ordinary least-squares fitted values from Table 2 (solid black line), a 45-degree line (short dashes) and the IV and RV (cross). The data are in percentage terms.

stems from both a reduction in the level of interest rates and greater certainty about both monetary policy and the level of real economic activity.

A close look at Figure 4 also hints that there might be some seasonal pattern in IV, associated with the expiry of contracts. Indeed, long-horizon IVs tend to be larger than short-horizon IVs (which, for brevity, are not shown). As IV is scaled to be interpretable as an annual measure, comparable at any horizon, this is a bit of a mystery. It might simply be an artifact of the simplifying assumptions of the BS model.

\section{What Sort of News Is Coincident with Changes in IV?}

Events of obvious economic importance and large changes in the futures price, itself, often accompany the largest changes in IV. To examine news events around large changes, the Wall Street Journal business section was searched for news on the dates of large changes and on the days immediately following those changes-from

\section{Table 2}

\section{Predicting Realized Volatility with Implied Volatility}

$\begin{array}{lr}\hat{\alpha} & -0.017 \\ \text { (s.e.) } & 0.052 \\ \hat{\beta}_{1} & 0.834 \\ \text { (s.e.) } & 0.064 \\ \text { Wald } & 40.814 \\ \text { Wald PV } & 0.000 \\ \text { Observations } & 3,952 \\ \text { R }^{2} & 0.599\end{array}$

NOTE: The table shows the results of predicting three-month eurodollar RV with IV, as in (8). The rows show $\hat{\alpha}$, its robust standard error, $\hat{\beta}_{1}$, its robust standard error, the Wald test statistic for the null that $\{\alpha, \beta\}=\{0,1\}$, the Wald test $p$-value, the number of observations, and the $R^{2}$ of the regression.

March 20, 1985, through June 29, 2001. Table 3 shows some of the largest changes in IV during the sample and the event that might have precipitated it.

The largest change in IV, by far, is a rise of 1.2 percentage points on October 20, 1987, coinciding with the stock market crash of 1987, when the S\&P 500 lost 22 percent of its value in one day. Four more of the top 20 changes (including the second largest) happened in the six weeks following the crash and one happened eight weeks before the crash, on August 27, 1987. The large changes in the IV of three-month eurodollar interest rates reflected uncertainty about future interest rates prior to the crash. A change in Federal Reserve Chairmen might have fueled the apparent uncertainty about the economy and the stance of monetary policy. Alan Greenspan took office as Chairman of the Board of Governors of the Federal Reserve on August 11, 1987.

The third largest change, a 0.44-percentagepoint increase, occurred on November 28, 1990. It coincided with reports that President George H.W. Bush would go to Congress to ask for endorsement of plans to use military force to evict Iraqi forces from Kuwait. The possibility of war in such an economically important area of the world clearly spooked financial markets. 


\section{Table 3}

\section{News Events Coincident with Large Changes in Three-Month Eurodollar IV}

\begin{tabular}{|c|c|c|c|c|}
\hline Rank & $\Delta$ in IV & Date & $\begin{array}{l}\Delta \text { in federal } \\
\text { funds target? }\end{array}$ & Relevant financial news \\
\hline 1 & 1.182 & $10 / 20 / 87$ & No & Stock market crash of 1987: S\&P 500 declined 22 percent in one day. \\
\hline 2 & -0.526 & $11 / 12 / 87$ & No & Decline in U.S. trade deficit. \\
\hline 3 & 0.438 & $11 / 28 / 90$ & No & $\begin{array}{l}\text { Gulf War fears: Bush going to Congress to ask for authority to evict } \\
\text { Iraq from Kuwait. }\end{array}$ \\
\hline 4 & 0.411 & $8 / 27 / 98$ & No & $\begin{array}{l}\text { Russian debt crisis: Yeltsin may resign, along with an indefinite } \\
\text { suspension of ruble trading and fear Russia may return to Soviet- } \\
\text { style economics. }\end{array}$ \\
\hline 5 & -0.375 & 1/15/88 & No & The sharp narrowing of the trade deficit triggered market rallies. \\
\hline 6 & 0.353 & $12 / 2 / 96$ & No & Retailers reported stronger-than-expected sales over Thanksgiving. \\
\hline 7 & 0.339 & $10 / 15 / 87$ & No & $\begin{array}{l}\text { Stocks and bonds slid further as Treasury Secretary Baker tried to } \\
\text { calm the markets, saying the rise in interest rates isn't justified. }\end{array}$ \\
\hline 8 & 0.332 & 9/3/85 & No & $\begin{array}{l}\text { The farm credit system is seeking a federal bailout of its } \$ 74 \text { billion } \\
\text { loan portfolio...As much as } 15 \text { percent of its loans are } \\
\text { uncollectible. }\end{array}$ \\
\hline 9 & 0.330 & $11 / 27 / 87$ & No & $\begin{array}{l}\text { Inflation worries remain despite the stock crash, due to higher } \\
\text { commodity prices and the weak dollar. }\end{array}$ \\
\hline 10 & -0.321 & $10 / 29 / 87$ & Yes & Post-stock market crash reduction in the federal funds target. \\
\hline 11 & 0.315 & 6/7/85 & No & $\begin{array}{l}\text { Bond prices declined for the first time in a week, as investors awaited } \\
\text { a report today on May employment...The Fed reported a surge } \\
\text { in the money supply, leaving it well above the target range. }\end{array}$ \\
\hline 12 & -0.302 & 10/30/87 & No & $\begin{array}{l}\text { Stocks and bonds reversed course after an early slide, helped by } \\
\text { G-7 interest-rate drops. }\end{array}$ \\
\hline 13 & -0.301 & $8 / 16 / 94$ & Yes & $\begin{array}{l}\text { FOMC meeting: The Fed boosted the funds rate } 50 \text { basis points, } \\
\text { sending a clear inflation-fighting message. }\end{array}$ \\
\hline 14 & -0.298 & $7 / 11 / 86$ & Yes & $\begin{array}{l}\text { The Fed's discount-rate cut prompted major banks to lower their } \\
\text { prime rates. }\end{array}$ \\
\hline 15 & -0.285 & $12 / 2 / 91$ & No & $\begin{array}{l}\text { Under strong pressure to resuscitate the economy, President } \\
\text { George H.W. Bush promised not to do "anything dumb" to } \\
\text { stimulate the economy. }\end{array}$ \\
\hline 16 & 0.279 & $4 / 20 / 89$ & No & $\begin{array}{l}\text { Financial markets were roiled by a surprise half-point boost in } \\
\text { West German interest rates. The tightening was quickly matched } \\
\text { by other central banks. }\end{array}$ \\
\hline 17 & 0.278 & $8 / 27 / 91$ & No & $\begin{array}{l}\text { Federal funds target rate was increased on August } 6 \text { and } \\
\text { September 13, } 1991 .\end{array}$ \\
\hline 18 & 0.275 & $8 / 31 / 89$ & No & $\begin{array}{l}\text { Federal funds target rate was increased on August } 20 \text { and October 18, } \\
1989 .\end{array}$ \\
\hline 19 & 0.275 & $8 / 27 / 87$ & Yes & Federal funds target rate raised by 12.5 basis points. \\
\hline 20 & 0.266 & $6 / 2 / 86$ & No & $\begin{array}{l}\text { Bond prices tumbled amid concern the economy will speed up, } \\
\text { renewing inflation. }\end{array}$ \\
\hline
\end{tabular}

NOTE: The table contains the largest changes in IV (in percentage points, in descending order) and the news (as reported in the Wall Street Journal) that was associated with those changes. The sample includes changes from March 20, 1985, through June $29,2001$. 
Another large increase, of 0.41 percentage points, occurred on August 28, 1998. This rise was coincident with the Russian debt crisis, rumors that President Yeltsin had resigned, and the possibility of a reversal of Russian political and economic reforms. The Russian debt crisis had potentially serious implications for international investors. Neely (2004c) discusses the episode and its potential effect on U.S. financial markets.

Several of the 20 largest changes in threemonth eurodollar IV were also associated with large changes in the futures price. It is likely that these changes in the futures price were unanticipated because large, anticipated changes in futures prices provide profit-making opportunities.

Additionally, anticipated changes are unlikely to cause a substantial revision to IV. Four of the 20 largest changes in IV were also associated with presumably unanticipated changes in the federal funds target rate. It seems that unanticipated monetary policy can be an important determinant of uncertainty about future interest rates.

Finally, one might note that the large IV changes shown in Table 3 refute the BS assumptions of a constant or even continuous volatility process. As such, they might be partly responsible for delta hedging errors, which require a risk premium that causes IV to be a conditionally biased estimate of RV.

\section{CONCLUSION}

This article has explained the concept of IV and applied it to measure uncertainty about three-month eurodollar rates. The IVs associated with three-month eurodollars can be interpreted to reflect uncertainty about the Federal Reserve's primary monetary policy instrument, the federal funds target rate.

As with IV in most financial markets, the IV of the three-month eurodollar rate has been an overly volatile predictor of RV. IV on the threemonth eurodollar rates has been declining since 1985, as inflation and interest rates have fallen and the Fed has gained credibility with financial markets. The largest changes in IV were coincident with important economic events such as the stockmarket crash of 1987, fears of war in the Persian
Gulf, and the Russian debt crisis. Most of the rest of the largest changes in IV have similarly been associated with important news about the real economy or the stock market or revisions to expected monetary policy.

\section{REFERENCES}

Ang, Andrew; Hodrick, Robert J.; Xing, Yuhang and Zhang, Xiaoyan. "The Cross-Section of Volatility and Expected Returns." Unpublished manuscript, Columbia University, 2003.

Barone-Adesi, Giovanni and Whaley, Robert E. "Efficient Analytic Approximation of American Option Values." Journal of Finance, 1987, 42, pp. 301-20.

Bates, David S. “Testing Option Pricing Models,” in G.S. Maddala and C.R. Rao, eds., Statistical Methods in Finance/Handbook of Statistics. Volume 14. Amsterdam: Elsevier Publishing, 1996.

Bates, David S. "Post-' 87 Crash Fears in the S\&P 500 Futures Option Market.” Journal of Econometrics, 2000, 94, pp. 181-238.

Bates, David S. "Empirical Option Pricing: A Retrospection." Journal of Econometrics, 2003, 116, pp. 387-404.

Beckers, Stan. "Standard Deviations Implied in Options Prices as Predictors of Futures Stock Price Variability." Journal of Banking and Finance, 1981, 5, pp. 363-81.

Benzoni, Luca. "Pricing Options Under Stochastic Volatility: An Empirical Investigation.” Unpublished manuscript, Carlson School of Management, 2002.

Black, Fischer. "The Pricing of Commodity Contracts." Journal of Financial Economics, 1976, 3, pp. 167-79.

Black, Fischer and Scholes, Myron. "The Valuation of Option Contracts and a Test of Market Efficiency." Journal of Finance, 1972, 27, pp. 399-417.

Blair, Bevan J.; Poon, Ser-Huang and Taylor, Stephen J. "Forecasting S\&P 100 Volatility: The Incremental Information Content of Implied Volatilities and 
High-Frequency Index Returns." Journal of Econometrics, 2001, 105, pp. 5-26.

Bollerslev, Tim and Zhou, Hao. "Volatility Puzzles: A Unified Framework for Gauging Return-Volatility Regressions." Finance and Economics Discussion Series 2003-40, Board of Governors of the Federal Reserve System, 2003.

Boyle, Phelim and Boyle, Feidhlim. Derivatives: The Tools that Changed Finance. London: Risk Books, 2001.

Campbell, John Y. "Intertemporal Asset Pricing without Consumption Data." American Economic Review, 1993, 83, pp. 487-512.

Canina, Linda and Figlewski, Stephen. "The Informational Content of Implied Volatility." Review of Financial Studies, 1993, 6, pp. 659-81.

Carlson, John B.; Melick, William R. and Sahinoz Erkin Y. "An Option for Anticipating Fed Action." Federal Reserve Bank of Cleveland Economic Commentary, September 1, 2003, pp. 1-4.

Chernov, Mikhail. "On the Role of Volatility Risk Premia in Implied Volatilities Based Forecasting Regressions.” Unpublished manuscript, Columbia University, 2002.

Christensen, B.J. and Prabhala, N.R. "The Relation Between Implied and Realized Volatility." Journal of Financial Economics, 1998, 50, pp. 125-50.

Dubofsky, David A. and Miller Jr, Thomas M. Derivatives: Valuation and Risk Management. New York: Oxford University Press, 2003.

Fleming, Jeff. "The Quality of Market Volatility Forecasts Implied by S\&P 100 Index Option Prices." Journal of Empirical Finance, 1998, 5, pp. $317-45$.

Heston, Steven L. "A Closed-Form Solution for Options with Stochastic Volatility with Applications to Bond and Currency Options." Review of Financial Studies, 1993, 6, pp. 327-43.

Hull, John C. Options, Futures, and Other Derivatives. 5th edition. Upper Saddle River, NJ: Prentice Hall, 2002.
Hull, John C. and White, Alan. "The Pricing of Options on Assets with Stochastic Volatilities." Journal of Finance, 1987, 42, pp. 281-300.

Jarrow, Robert and Turnbull, Stuart. Derivative Securities. Cincinnati, OH: South-Western College Publishing, 2000.

Johnston, E.; Kracaw, W. and McConnell, J. "Day-ofthe-Week Effects in Financial Futures: An Analysis of GNMA, T-Bond, T-Note, and T-Bill Contracts." Journal of Financial and Quantitative Analysis, 1991, 26, pp. 23-44.

Jorion, Philippe. "Predicting Volatility in the Foreign Exchange Market." Journal of Finance, 1995, 50, pp. 507-28.

Kroner, Kenneth F.; Kneafsey, Kevin P. and Claessens, Stijn. "Forecasting Volatility in Commodity Markets.” Working Paper 93-3, University of Arizona, 1993.

Krueger, Joel T. and Kuttner, Kenneth N. "The Fed Funds Futures Rate as a Predictor of Federal Reserve Policy,” Working Paper WP-95-4, Federal Reserve Bank of Chicago, March 1995.

Lamoureux, Christopher G. and Lastrapes, William D. "Forecasting Stock-Return Variance: Toward an Understanding of Stochastic Implied Volatilities." Review of Financial Studies, 1993, 6, pp. 293-326.

Latane, Henry A. and Rendleman, Richard J. Jr. "Standard Deviations of Stock Price Ratios Implied in Option Prices.” Journal of Finance, 1976, 31, pp. 369-81.

Li, Kai. "Long-Memory versus Option-Implied Volatility Prediction." Journal of Derivatives, 2002, 9, pp. 9-25.

Martens, Martin and Zein, Jason. "Predicting Financial Volatility: High-Frequency Time-Series Forecasts vis-à-vis Implied Volatility." Journal of Futures Markets, 2004, 24(11), pp. 1005-28.

Merton, Robert C. "An Intertemporal Capital Asset Pricing Model.” Econometrica, 1973a, 41, pp. 867-87. 


\section{Neely}

Merton, Robert C. "Theory of Rational Option Pricing., Bell Journal of Economics, 1973b, 4(1), pp. 141-83.

Neely, Christopher J. "Realignments of Target Zone Exchange Rate Systems: What Do We Know?” Federal Reserve Bank of St. Louis Review, September/October 1994, 76(5), pp. 23-34.

Neely, Christopher J. "Forecasting Foreign Exchange Volatility: Why Is Implied Volatility Biased and Inefficient? And Does It Matter?" Working Paper 2002-017D, Federal Reserve Bank of St. Louis, 2004a.

Neely, Christopher J. "Implied Volatility from Options on Gold Futures: Do Econometric Forecasts Add Value or Simply Paint the Lilly?” Working Paper 2003-018C, Federal Reserve Bank of St. Louis, 2004b.

Neely, Christopher J. "The Federal Reserve Responds to Crises: September 11th Was Not the First." Federal Reserve Bank of St. Louis Review, March/ April 2004c, 86(2), pp. 27-42.

Pakko, Michael R. and Wheelock, David. "Monetary Policy and Financial Market Expectations: What Did They Know and When Did They Know It?” Federal Reserve Bank of St. Louis Review, July/ August 1996, 78(4), pp. 19-32.

Pan, Jun. "The Jump-Risk Premia Implicit in Options: Evidence from an Integrated Time-Series Study.” Journal of Financial Economics, 2002, 63, pp. 3-50.

Poteshman, Allen M. "Forecasting Future Volatility from Option Prices.” Unpublished manuscript, Department of Finance, University of Illinois at Urbana-Champaign, 2000.
Romano, Marc and Touzi, Nizar. "Contingent Claims and Market Completeness in a Stochastic Volatility Model.” Mathematical Finance, 1997, 7, pp. 399-410.

Rose, Andrew K. and Svensson, Lars E.O. "Expected and Predicted Realignments: The FF/DM Exchange Rate During the EMS.” International Finance Discussion Paper Number 395, Board of Governors of the Federal Reserve System, April 1991.

Rose, Andrew K. and Svensson, Lars E.O. "European Exchange Rate Credibility Before the Fall.” NBER Working Paper No. 4495, National Bureau of Economic Research, October 1993.

Shleifer, Andrei, and Vishny, Robert W. "The Limits of Arbitrage.” Journal of Finance, 1997, 54, pp. 35-55.

Svensson, Lars E.O. "The Simplest Test of Target Zone Credibility.” IMF Staff Papers, September 1991, pp. 655-65.

Szakmary, Andrew; Ors, Evren; Kim, Jin Kyoung and Davidson, Wallace N. III. "The Predictive Power of Implied Volatility: Evidence from 35 Futures Markets." Journal of Banking and Finance, 2003, 27, pp. 2151-75.

Wilmott, Paul; Howison, Sam and Dewynne, Jeff. The Mathematics of Financial Derivatives: A Student Introduction. Cambridge: Cambridge University Press, 1995.

Wilmott, Paul. Paul Wilmott on Quantitative Finance. Chichester, UK: John Wiley \& Sons, 2000. 


\section{GLOSSARY}

A European option is an asset that confers the right, but not the obligation, to buy or sell an underlying asset for a given price, called a strike price, at the expiry of the option.

An American option can be exercised on or before the expiry date. ${ }^{1}$

Call options confer the right to buy the underlying asset; put options confer the right to sell the underlying asset.

If the underlying asset price is greater (less) than the strike price, a call (put) option is said to be in the money. If the underlying asset price is less (greater) than the strike price, the call (put) option is out of the money. When the underlying asset price is near (at) the strike price, the option is near (at) the money.

The firm or individual who sells an option is said to write the option.

The price of an option is often known as the option premium.

1 The terms European and American no longer have any geographic meaning when referring to options. That is, both types of options are traded worldwide. 
